Acta Oeconomica, Vol. 64 (4) pp. 481-509 (2014)

DOI: 10.1556/AOecon.64.2014.4.5

\title{
THE ROLE OF EXPECTATIONS IN AUSTERITY CYCLES: THE POLITICAL ECONOMY OF CRISIS MANAGEMENT IN IRELAND AND GREECE*
}

\author{
Dóra GYŐRFFY \\ (Received: 7 September 2013; revision received: 30 October 2013; \\ accepted: 13 January 2014)
}

\begin{abstract}
The main goal of the paper is to explain the role of expectations in austerity cycles during financial bailouts. The paper presents a political economy model of bailouts, where the conditions, their implementation, and market reception are considered as forms of a social dilemma. In such situations, expectations about the actions of other actors approximated by the concepts of trust or distrust play a critical role. An environment of trust is conducive to mitigating the size and effects of fiscal contraction, while an environment of distrust is likely to magnify both. It is also argued that the credibility of government is the key driving force in these self-reinforcing cycles. The crisis management experiences of Greece and Ireland serve to illustrate the theoretical model.
\end{abstract}

Keywords: austerity cycles, financial crisis management, trust, Greece, Ireland

JEL classification indices: F34, F50, H60

* I am grateful to László Csaba, Péter Mihályi and the two anonymous referees for their helpful comments on earlier versions of this paper. The research was supported by TÁMOP Grant 4.2.1 B-11/2/KMR-2011-0002 of the Hungarian government and the European Union as well as the Bolyai fellowship from the Hungarian Academy of Sciences.

Dóra Györffy, Associate Professor at the Institute of International Studies and Political Science, Péter Pázmány Catholic University. E-mail: gyorffydora@t-online.hu 
Since 2009, the Euro zone has been hit by an unprecedented series of crises. Several countries were forced to accept bailouts and implement domestic austerity policies. The lagging recovery challenged earlier theories regarding fiscal consolidations and called attention to self-defeating austerity cycles, when the recession leads to both lower tax revenues and higher debt rates due to expenditure cuts, and thus necessitates more austerity (Krugman 2013).

At the same time, we can also see that not all consolidations led to austerity spirals and thus the question emerges about the underlying mechanism of these cycles. In this study I will consider the experiences of Greece and Ireland, and compare the sources and outcomes of austerity policies. Both countries undertook substantial fiscal consolidation over $20 \%$ of the GDP. However, while Ireland experienced a moderate recovery, growth collapsed in Greece. Since both countries are in the Euro area thus do not have recourse to devaluation or cutting interest rates, and both undertook austerity measures during a global recession, their comparison can shed light on the conditions under which an austerity spiral can be avoided.

In order to explain the difference between the two cases, I will interpret the design and implementation of financial bailout as a multiple-level social dilemma. Social dilemmas are situations when individual and collective rationality conflict. Resolving such situations requires substantial trust among actors, and when it is missing, a collectively suboptimal equilibrium emerges. In the paper I will argue that a persistent lack of trust among the main actors lies at the heart of austerity spiral in Greece, while trust based on shared economic ideas and consistent practices in Ireland mitigated the negative effects of austerity.

The paper proceeds as follows. First, I will provide a brief overview of the recent debate over austerity and the possibility for expansionary fiscal consolidations. Then I will present a theoretical framework, which discusses the role of expectations in the success of bailout packages at three levels: the establishment of conditions, the domestic reception of these conditions, and the market reaction to their implementation. In the second part of the paper, I will apply this framework to the cases of Greece and Ireland and show how it can help to explain their different experiences with crisis management.

\section{THE DEBATE OVER AUSTERITY}

During the 1990s, the idea that austerity policies can have non-Keynesian effects increased the commitment to expenditure-based fiscal consolidation. On the basis of experiences from the OECD countries since 1970, a large literature developed on the conditions under which fiscal consolidation might be expansionary 
(Giavazzi - Pagano 1990; Alesina - Perotti 1995; Alesina et al. 1998). The main finding was that consolidations based on cuts in spending rather than tax hikes are less likely to hurt economic growth. Few questioned these results until the global financial crisis, when numerous countries had to go through sharp adjustments simultaneously.

The recessionary effects of austerity policies led to highly politicised debates regarding the appropriate response to the crisis, and the findings about the possibility for expansionary consolidation were challenged, too. An IMF paper found that the periods of expansionary consolidations generally took place during an economic boom, when interest rates could fall with increased confidence or the devaluation of the currency could raise exports. At the same time, if interest rates are at the zero-bound, there is no possibility of devaluation and global demand is low, fiscal consolidations are likely to be contractionary with a fiscal multiplier averaging 0.5 . This means that "a fiscal consolidation equal to $1 \%$ of GDP typically reduces GDP by about $0.5 \%$ within two years" (IMF 2010c: 94 ).

Perotti (2011) reached similar conclusions by looking closely at the model cases of expansionary fiscal consolidations (Denmark, Finland, Ireland, and Sweden). He found that the main drivers of the expansion were the depreciation of the currency, increases in exports, falling interest rates, and wage moderation. The usefulness of such measures are highly questionable during a global crisis - if all countries introduce austerity at the same time, global demand contracts and the potential for export-led recovery is reduced for all.

The empirical evidence from the current consolidation supports the critics of expansionary fiscal consolidations and shows an even larger short-term tradeoff between austerity and growth than previously assumed. De Grauwe - Ji (2013) find a strong negative correlation between the size of fiscal consolidation and growth. They also find that in the Euro zone, consolidation does not appear to have effects on market confidence as interest rates are negatively related to consolidation efforts. Furthermore, the size of contraction is also larger than previously thought. On the basis of 26 advanced economies, Blanchard - Leigh (2013) found that during the early part of the crisis, the size of the multipliers had been grossly underestimated - i.e. they were substantially above the previously calculated 0.5 value.

Overall, the pre- and post-crisis literature arrives to different results regarding fiscal consolidations. While the possibility for non-Keynesian effects and the importance of the composition of adjustment were emphasised during the 1990s, in a period of global recession concerns over output costs regardless of composition became stronger. At the same time, the dominance of context in the statistical results hides important cross-country differences regarding the effects of austerity and the mechanisms driving austerity spirals. Looking at case studies is a useful 
method in analysing the causal links through which output collapse takes place as a response to austerity. While they are rarely suitable for testing theories, they can be used for illustrating new theoretical insights (Durlauf 2001; George - Bennett 2005).

\section{THEORETICAL FRAMEWORK: TRUST AND AUSTERITY SPIRALS}

\subsection{Social dilemmas and trust}

Fiscal adjustments, which take place as conditions for a financial bailout package, involve social dilemmas at multiple levels, which necessitate trust among actors. For the purposes of this paper, I use the concept of trust as a positive expectation about the willingness and capacity of other independent and unrelated actors to live up to their commitments. In the following, I will provide a brief overview about social dilemmas and the necessity of trust, and then address how these are applicable during the stages of bailout negotiations and implementation.

Social dilemmas are situations when individual and collective rationality conflicts, and following individual rationality lead to collectively sub-optimal outcomes. This problem is usually illustrated by the prisoners' dilemma, when cooperation entails substantial risks but non-cooperation leads to substantial losses for all actors. The solution to such situations can come from information on the motives of other, third-party enforcement of cooperative action, and repeated interaction, which illustrates the costs of non-cooperation (Axelrod 1984).

However, it has also been recognised that social dilemmas cannot be resolved in a satisfactory manner in a rational choice framework. For a utility-maximising, self-interested agent, the temptation to free-ride will eventually prevail. Under these conditions, without trust in other players, the most likely outcome is to end up in a social trap, where all players are worse off compared to the case of cooperation (Rothstein 2000: 482).

The literature on trust provides several answers to the question regarding the origins of trust. From a rational choice perspective, trust means "encapsulated interests" - A trusts B if he/she knows that B's incentive structure is such as to live up to its commitment to A (Hardin 1998). The credibility and reputation of B thus play a critical role in establishing such trust. However, trust also has non-rational motives, since it concerns beliefs about the future and we cannot have certainty about it. It is thus an expectation, which can be right or wrong. Scholars trying to transcend the game theoretic paradigm on trust have emphasised the role of shared collective memories (Rothstein 2000: 483) as well as shared beliefs and ideas 
(Sabatier - Jenkins-Smith 1988) as crucial in fostering trust and easing cooperation over difficult issues.

In the following, I will consider the role of trust at three stages of bailouts: negotiating the conditions, implementing the agreement, and the market reception of the measures. Finally, I will show the interactions among these variables and discuss their relation to the emergence of austerity spirals.

\subsection{Negotiating conditions for bailouts}

When a country asks for a loan-financed bailout, the fundamental problem of asymmetric information arises, which characterises all financial transactions. The borrower knows more about her situation than the lender, and thus after receiving the funds a moral hazard problem appears. The borrower may have incentives to use the funds differently then was negotiated with the lender or not pay back the funds. Such a risk is generally handled by collateral or an interest premium in the markets. However, since countries in trouble cannot pledge internationally valuable collaterals and the required risk-premium might be prohibitive, the IMF imposes conditionality, which ensures the repayment of loans as a substitute for collateral (Kahn - Sharma 2006: 121).

At the same time, conditionality in itself does not necessarily solve the problem, since unlike a private institution, the IMF cannot just walk away from the program and cut the losses (Kahn - Sharma 2005: 122). This is why country ownership of the program is critical - it aligns the incentives of lenders and borrowers. Ownership means "the extent to which a country is interested in pursuing reforms independently of any incentives provided by multinational lenders" (Drazen 2002: 37).

However, in examining the relationship between conditionality and ownership, Drazen (2002: 40) calls attention to a basic tension between conditionality and ownership: why is conditionality needed if the conditions are in the best interest of the country as argued by the IMF? In order to answer this puzzle Drazen focuses on conflict of interest not between lender and borrower but rather among interest groups in the domestic countries - by imposing certain conditions on a country, the multinational lender community strengthens domestic forces interested in reforms and weakens groups opposing reforms. The IMF has designed several mechanisms, which are meant to strengthen domestic ownership of programs. The most important ones are encouraging countries to design their own programs, streamlining structural conditionality to provide more room for democratic decision-making, adopting floating tranche conditionality, and focusing on outcomes rather than policies (Khan - Sharma 2006: 125-128). 
Using these methods, however, still does not solve the essential problem of moral hazard and negate the importance of trust between lender and borrower. The IMF has to agree to home-grown programs in order to ensure the repayment of loans. A certain amount of confidence that the program will work and produce the targeted outcomes is necessary. Floating tranche conditionality ensures the continued incentive to implement the program and produce the outcome, but there is still substantial judgment involved. As described above, being a cooperative institution, the IMF cannot easily walk away from programs and has a clear interest in their success. This also questions outcomes conditionality since unexpected events can take place, which might make the terms of the original contract unrealistic. Judgment and politics play a great role in assessing such situations. In these cases, trust among actors is critical.

The origins of such trust are multiple and include prior history of successful cooperation as well as belief in the capability and willingness of the administration to design and implement a successful program. Finally, as described in the theoretical framework on the origins of trust in a bureaucracy, ideational commonality is a major basis for trust. Thus, capable administrations, which share the fundamental outlook of IMF officials, are likely to get more freedom in designing their programs and having more room for mistakes than those, which have a poor history of cooperation, unable to design an acceptable program and do not share the economic philosophy of the IMF.

\subsection{Public attitudes - implementing the bailout}

Ownership and the domestic design of the package do not occur in a vacuum. The public needs to believe that the sacrifices are worthwhile. A major advantage of public trust is to serve as "a reserve of support that enables a system to weather the many storms when outputs cannot be balanced off against inputs of demands" (Easton 1965: 273). This implies that when potentially difficult changes have to be made, the government is able to implement first-best measures, even if they might be painful for the population in the short-term. In such a scenario, the perception of the public about the competence and integrity of the government makes the demands for sacrifice acceptable. In countries, where the legitimacy of the government is based on short-term, populist measures rather than competence and integrity, long-term promises are not believed and strong resistance is likely to emerge against measures which are painful in the short-term. As a consequence, policy-makers try to avoid them and navigate among the political constraints when they face the need for adjustment (Győrffy 2009, 2013). 
In terms of fiscal consolidation this means that in a low-trust environment, the method of consolidation is likely to be sub-optimal - the primary motive in the decision over consolidation methods is likely to be short-term political rather than long-term economic. Short-term political perspective is likely to opt for raising taxes rather than cutting expenditures - especially cash transfers, which are most visible for the public. As discussed in the previous part, in the 1990s revenuebased consolidations had clearly inferior results to expenditure-based strategies.

Trust in the government generally depends on perceived intentions and capabilities (Rosanvallon 2008: 3-4). Both factors are critically affected by earlier periods of consolidation - memories of success or unnecessary hardship are likely to play an important role for public support. If the public does not believe that the policies are designed for the common good but rather focus on particular interest groups, they are unlikely to accept the sacrifices asked. In this context, the fairness of adjustment is critical - if an effort is made to distribute the burdens fairly, public support for the adjustment is more likely. According to Stix (2013), the concern for fairness is present both among the current generation and in the intergenerational context. He also found that low trust in the success of the plans lowers public support.

\subsection{Market trust - reception of the bailout package}

The major aim of bailout packages is to help countries return to market financing. In order to achieve this, trust in the capability of repaying the loans is necessary. However, market trust also exhibits social dilemma features. A given set of fundamentals might be consistent with multiple equilibria, which means that if investors believe in a country's ability to repay its loans it can, but if they lose this belief, a self-fulfilling crisis can take place (Obstfeld 1996; Jeanne 1997).

It has long been recognised that the trust of markets is partly driven by Keynesian animal spirits, which is "a spontaneous urge to action rather than inaction, and not as the outcome of weighted average of quantitative benefits multiplied by quantitative probabilities" (Keynes 1936: 161-162). The presence of animal spirits can give rise to cycles of confidence when increasing prices increase confidence, reinforcing the rise in prices. This phenomenon has been recognised by investment practitioners (Soros 1987), behavioural economists (Shiller 2000) as well as empirical analyses of financial crises (Kindleberger 1989; Reinhart Rogoff 2009). In all accounts, efforts to rationalise confidence play a critical role in sustaining the cycle.

While animal spirits play an important role in creating boom and bust on the financial markets, rational bases for trust cannot be dismissed. Countries with a his- 
tory of serial default and high inflation face serious constraints in gaining market access and exhibit features of debt intolerance, which means they might face a loss of trust at much lower levels of debt than other countries with a better track record (Reinhart et al. 2003). Present policies also influence market perceptions. One of the main claims of the literature on expansionary fiscal consolidations was that painful expenditure-based consolidations signal the commitment of policy-makers to stabilisation and thus increase positive expectations on the financial markets (Alesina et al. 1998).

One of the ways an IMF bailout is supposed to work is through catalysing private lending. It is believed that once a country achieves the seal of approval for its adjustment program, markets are more likely to believe in its success than otherwise. Belief in the success of the program in turn reduces the burden of adjustment on the debtor country. However, as Cottarelli - Giannini (2006) acknowledges, empirical evidence for such effect is small. By reviewing the possible channels through which this effect might work (provision of assistance, information, commitment technology, screening device, and liquidity), they note the uncertainty regarding the conditions for such methods to work, which include the problems noted above regarding IMF lending - asymmetric information, potential for breaching the contract, and the role of judgment over non-compliance.

The above problems also imply that markets are also paying attention to domestic factors, which influence the behaviour of policy-makers. In case of strong resistance and lack of public support for the package, concerns of sustainability might emerge.

\subsection{Trust and austerity spirals}

In the various relationships, which were discussed above, we find trust in government at the centre. Such trust in government is strongly related to the credibility of the government, which can be defined as its willingness and ability to live up to its promises. A government, which lacks such credibility, is likely to face tougher and more severe conditions in order to receive the bailout than a government, whose promises are believed. The tougher conditions increase public resistance, which in turn lowers market confidence.

All these factors contribute to program failure: tougher conditions are more difficult to fulfil, greater public resistance increases the incentives for non-compliance, while lack of market confidence increases the need for adjustment. Failure of the program further reduces the credibility of the government and thus the cycle is reinforced. A graphic representation of this phenomenon is shown in Figure 1 .

Acta Oeconomica 64 (2014) 


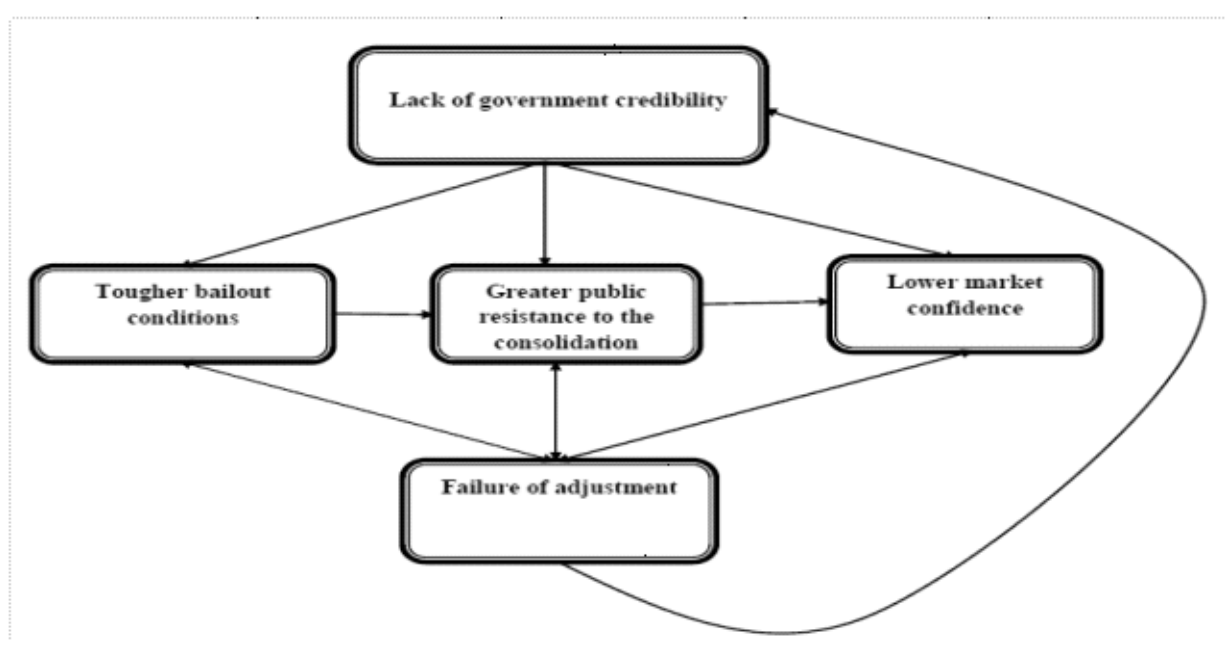

Figure 1. Lack of government credibility and austerity spirals

Naturally, the model does not aim to imply that government credibility is the sole determinant of the conditions of bailout packages. As any model, which aims to highlight the contribution of a particular factor to an outcome of complex interactions, it should be interpreted under ceteris paribus conditions.

\section{THE ROAD TO CRISIS IN GREECE AND IRELAND}

Before applying the theoretical framework to the crisis management experiences of Greece and Ireland, it is unavoidable to briefly summarise the differences in the economic system and the nature of the crisis in the two countries.

\subsection{Collective memories}

Economic success in the Irish collective memory is deeply tied to the export-oriented strategy, which placed the attraction of FDI into the centre of policy since the 1950s. This orientation was strengthened after 1987, when a neo-corporatist system was established in which social partners could agree in fiscal consolidation measures, as well as wage moderation and other labour market issues. Such an arrangement created a stable and peaceful environment for business planning and made the country even more attractive to FDI (Boltho 2000).

Following the Social Pact, the country implemented fiscal consolidation and reduced its level of debt from 111.5 to $31.5 \%$ by 2000 (European Commission 
2013b: 184). Cutting both expenditures and taxes state redistribution also fell sharply from 50.8 to $31.2 \%$ during the same period (European Commission 2013b: 178), resulting in a liberal regime of low taxes and need-based social policies. Due to the parallel devaluation of the Irish pound - especially against the British pound due to the Lawson boom - a large export increase followed the consolidation with an average increase of 10\% between 1987 and 1990 (Perotti 2011: 26). ${ }^{1}$

During the next two decades, Ireland emerged from the periphery of Europe to a model case of development. Just before the crisis in 2007, GDP per capita adjusted for purchasing power parity stood at $147 \%$ of the EU average, and the country was second on this indicator after Luxembourg. The enormous successes following a period of sharp fiscal consolidation and liberalisation imply a strong foundation for neoliberal policies. Such a memory provided a very different background to crisis management than the pre-crisis politics in Greece.

From the 1980s, Greece had an inward-oriented economic agenda, where the state played a growing role as provider of jobs and welfare benefits. Nationalisations and the creation of a large number of new state agencies provided safe and high-paying jobs to supporters of the governing party, and pensioners received large increases in their benefits (Chrysoloras 2013: 12). While the public sector employed 350,000 people in 1981, this number grew to 616,000 by 1992 (Iokamidis 2001: 77). The enormous expansion of the public sector contributed to large fiscal deficits during the entire period and resulted in a sharp rise of public debt from $26.7 \%$ of the GDP in 1981 to $79.1 \%$ by 1991 (European Commission 2013b: 184).

During the 1990s, the accession process to the Economic and Monetary Union led to reform attempts including privatisation of state enterprises as well as a reduction of fiscal deficits. This stopped the further accumulation of debt and the country introduced the euro - although, in retrospect, we know that the country never reached the $3 \%$ deficit threshold. ${ }^{2}$ Following the accession to the Euro zone, fiscal deficits returned, and expenditures were steadily over revenues. Given the sharp decline in interest rates following the introduction of the euro, ${ }^{3}$ budgetary consolidation could take place without structural reforms and the government was able to raise wages and social benefits. Employment figures also reflected the

1 For a deeper explanation of the origins of the Irish economic miracle, see the volume edited by Barry (1999).

2 While other countries also used creative accounting techniques to enter the Euro zone, Loizides (2013) shows that Greece reported the least reliable deficit figures and had the largest dispersion of revisions within the EU between 1991 and 2012.

3 While in 1992 long-term interest rates stood at $24.1 \%$, by 2005 they fell to $3.6 \%$ (European Commission 2013b: 126). 
growth of the state - by 2009, public sector employment reached 1,200,000 out of a labour force of around 5,000,000 (Visvizi 2012: 18).

The expansion of the state implied extensive regulation of business. Product and labour market regulations have been long assessed as the most extensive in the EU (Iokamidis 2001: 77). The overregulation of the private sector provided enormous opportunities for corruption and the functioning of a shadow economy, which is around 30\% of the official economy in Greece (OECD 2010: 10). Such an environment was far from attractive to private investment, and growth was primarily driven by the large-scale public investments in preparation for the 2004 Olympic Games as well as the inflow of cheap credit, which fuelled consumption (Chrysoloras 2013: 17). ${ }^{4}$

Overall, unlike in Ireland, the popularity of government was based on providing jobs in the public sector and maintaining high levels of consumption rather than on ensuring the competitiveness of the economy.

\subsection{The outbreak of the crisis}

Based on the above description, it is not surprising that Greece became victim of the global financial crisis. According to Gibson et al. (2011: 9-10) and Visvizi (2012: 21), a major reason for the loss of confidence was the revision of deficit data by the newly elected PASOK government in October 2009. The figure was revised to $12.7 \%$ of GDP, up from the $6 \%$ original projection of the previous government. This was then followed in December by the admission that public debt reached $€ 300$ bn or $113 \%$ of the GDP. The two announcements were quickly followed by downgrades from the major rating agencies. Afterwards, interest rates rose sharply and Greece lost access to the international financial markets.

Ireland's path to the crisis was somewhat more complicated and originates from its earlier success. Following the entry into the Euro zone, the country experienced negative real interest rates for almost 10 years. The rate set by the ECB proved to be too low for this buoyant economy, as given the high rates of growth, inflation was regularly over the Euro zone average. The enormous inflow of foreign capital further encouraged borrowing. Given the widespread increase in credit, housing prices soared, which started a bubble as expectations about further price increases were built up into current prices and investment into real estate increased further (Honohan 2009: 210-216). These processes gave rise to a familiar cycle of overheating involving rising private consumption, erosion of wage moderation, inflation, loss of competitiveness, and growing current account deficits.

4 In the Greek GDP the share of consumption is over $70 \%$, which is much higher than the $57 \%$ average of the Euro zone (European Commission 2013b: 54). 
Thus, from 2001 onwards, the Irish growth model began to change, and construction took over the lead from exports as the leading sector.

As Honohan (2010: 32) argues, the bubble would have burst even without the international crisis as house prices had been already falling for 18 months prior to the collapse of Lehman Brothers. The banks involved in real estate lending were thus on the road to insolvency. The contribution of the international crisis to the domestic problems was that soft landing became impossible.

Once the international financial markets froze and the Irish banks could not roll-over their short-term debt, immediate government intervention became necessary for saving the financial system. According to the latest estimates, the total cost of these measures was over $40 \%$ of the GDP at $€ 64$ bn (Hardiman - Regan 2013: 10). At the same time, the international crisis depressed foreign trade as well, thus domestic and external demand both collapsed leading to a sharp fall of GDP - a drop of $3.5 \%$ in 2008 , followed by $7.6 \%$ in 2009 - and an increase in unemployment to over $12 \%$. The subsequent collapse of revenues ${ }^{5}$ and the rise in expenditures together with the costs of bank consolidation resulted in a fiscal deficit of $30.8 \%$ of GDP in 2010, while public debt surpassed $100 \%$ by 2011 from $25 \%$ in 2007 (European Commission 2013b: 180, 184). All these developments led to doubts about Ireland's ability to pay its liabilities, and a vicious cycle of high interest rates and increased scepticism about debt service developed. Ireland had to ask for a multilateral bailout in November 2010.

Overall, in spite of the different origins of their problems, in 2010 both Greece and Ireland engaged in bailout negotiations with the Troika (European Commission, European Central Bank and the IMF), and subsequently implemented similar austerity measures. Understanding the political economy considerations behind the negotiation and implementation of the bailout on the basis of the theoretical framework will take us closer to understand why a severe austerity spiral developed in Greece and not in Ireland.

\section{NEGOTIATING THE BAILOUT}

\subsection{Greece}

Trust towards Greece was low from the beginning of negotiations. The country had regularly falsified statistics and the outbreak of the crisis was viewed as a just

5 According to Regling - Watson (2010: 27), revenues collapsed, given the strong reliance on cyclically sensitive taxes such as stamp duties, capital gains tax, and corporation tax. Starting from the 1990s, a substantial shift took place in the composition of tax revenue and the share of such taxes increased from 8 to $30 \%$.

Acta Oeconomica 64 (2014) 
punishment for this practice. Even in March 2010, Angela Merkel denied the possibility of a Greek bailout, noting the non-bailout clause of EU and called Greece first to fulfil its duties and restore its lost credibility. ${ }^{6}$

Following months of inaction and high level of uncertainty on the global financial markets, the EU authorities and the IMF agreed to provide Greece a $€ 110$ bn loan over three years in May 2010. Euro zone member states provided $€ 80$ bn, while the IMF financed the remaining $€ 30$ bn within a standby agreement. The package was conditional upon the implementation of fiscal consolidation - bringing down the deficit to $3 \%$ by 2014 - as well as far-reaching structural reforms. ${ }^{7}$ While the size of fiscal adjustment was not unprecedented, Ardagna - Caselli (2012: 7-8) argue that two factors made it extremely unlikely to succeed: the scale of recession in Greece and around the world, and the lack of recourse to exchange rate adjustment - both of these factors were present during similar scale fiscal consolidations and eased the pain of adjustment.

While Greece implemented substantial adjustments, cutting wages and pensions as well as raising taxes, ${ }^{8}$ by 2011 it became evident that the program was unlikely to succeed and Greece would be unable to return to market financing. According to Ardagna - Caselli (2012: 21), there were two major reasons. First, the revision of the 2009 deficit from 14 to $16 \%$ meant a much larger need for adjustment than thought during the signing of the bailout program. Second, the Irish bailout implied continued market uncertainty, which made it impossible to return to market financing. Visvizi (2012: 29-30) also notes the worse than expected downturn (Figure 3), which led to the country missing the deficit target (Table 1). Furthermore, she also argues that the excessive focus on fiscal balance yielded the wrong set of policies - while Greece suffered severe structural problems from excessive state intervention, most of measures focused on raising expenditures and fighting tax evasion, which further worsened the business environment and led to the collapse of investments. At the same time, privatisation, which would have been a clear way to raise revenue and improve productivity, was not even considered (Visvizi 2012: 33).

Following the bailout and the austerity measures, the Greek economy kept shrinking (Figure 6), which made consolidation all the more painful. At the same

6 As reported by Economic Policy Journal on February 28, 2010. Available: http://www.economicpolicyjournal.com/2010/02/merkel-no-greek-bailout.html. Accessed: 27 July, 2013.

7 Detailed conditions are available in European Commission (2010).

8 Some of the measures included increases in VAT and excise tax, cuts in public investments, capping 13th and 14th month salaries, freezing recruitment in the central government sector, raising of the retirement age, and penalties for early retirement in the pension system. (See Monastiriotis 2013: 5-6.) 
Table 1

Fiscal balance criteria and performance in Greece and Ireland

\begin{tabular}{lrrrrrrr}
\hline & 2009 & 2010 & 2011 & 2012 & 2013 & 2014 & 2015 \\
\hline Greece 2010 & -13.6 & -8.0 & -7.6 & -6.5 & -4.9 & -2.6 & \\
Greece 2012 & -15.8 & -10.6 & -9.3 & -7.3 & -4.6 & -2.1 & \\
Greece actual & -15.7 & -10.9 & -9.6 & -8.9 & -12.7 & $-1,6^{*}$ & \\
Ireland & -14.4 & -32.0 & -10.6 & -8.6 & -7.5 & -5.1 & -2.9 \\
Ireland actual & -13.7 & -30.6 & -13.1 & -8.2 & -7.2 & $-4.8^{*}$ & \\
\hline
\end{tabular}

Note: *forecast

Sources: On criteria: European Commission (2010: 13, 2011: 29, 2012b: 16), on actual performance: European Commission (2014: 180).

time, the crisis in the Euro zone reached further countries, and given the anxiety over the Irish and then the Portuguese bailout in May, Greece was unable to return to the international financial markets in 2011. Investors did not believe it would be able to finance its liabilities and thus it was not. The insistence of Germany on private sector involvement in the management of the crisis made investors even more wary (Ardagna - Caselli 2013: 22).

While the need for a second bailout was evident during early 2011, a new agreement was signed only in February 2012. Distrust among the partners was a clear reason for this delay. Greece was an ideal target for being a scapegoat. Added to its history of populist policies and statistical manipulation, the country missed the deficit targets during the first two years of the bailout (2010-2011) by a large margin (Table 1). Furthermore, an intensification of mutual resentment took place between Greece and its creditors, especially Germany. While Greeks blamed Germans for imposing enormous austerity on the country in return for the bailout, Germans saw Greeks protesting and negating the conditions, while they were asked to pay. ${ }^{9}$ In a survey conducted in January 2012 , only $30 \%$ of the 5000 respondents supported unchanged or greater participation of Germany in the European bailout funds (Bechtel et al. 2012).

Prior to signing the second bailout, further deterioration of trust took place among negotiating partners. The painful adjustment initiated widespread protests in Greece. For domestic political reasons the prime minister, George Papandreou proposed a referendum on the bailout conditions - he wanted to implicate the opposition party New Democracy in order to mitigate the political costs of the bailout. Under pressure from his European partners threatening of EU exit, he was forced to cancel the referendum and resign. He was replaced by former ECB Vice

The media coverage of the bailout in the two countries is summarised in The Guardian, June 21, 2011. Article available: http://www.guardian.co.uk/world/2011/jun/21/german-mediabild-greece-bailout-resentment. Accessed: July 27, 2013.

Acta Oeconomica 64 (2014) 
President Loukas Papdemos, who received a temporary mandate as head of a grand coalition government (government of national unity) until the elections scheduled to May 2012.

The second bailout of $€ 130$ bn was finally in February 2012. The package was accompanied by private sector involvement in debt reduction, which essentially meant the write-down of $53.5 \%$ of the Greek public debt. ${ }^{10}$ Unlike the first package, in which the Greek government successfully focused on raising taxes rather than cutting expenditures, the second package allowed the government much less discretion and focused more strongly on the expenditure side. Structural reform conditionality also became much stricter and extremely detailed measures were prescribed in the areas of public sector functioning, labour and product markets, financial system, and the judiciary. ${ }^{11}$ The numerical conditions of the agreement were even harsher than the previous one and aimed to achieve a primary surplus target of $4.5 \%$ of GDP by 2014 and a debt rate under $120 \%$ by 2020 (European Commission 2012b: 16). As emphasised by Ardagna - Caselli (2012), these conditions were much tougher than any previous fiscal consolidation in the OECD countries during the past 40 years.

The deal was signed amid the run-up to the elections in May. In the campaign, the major opposition party, SYRIZIA, the Coalition of the Radical Left - Unitary Social Front called for the revision of the agreement. The difficulties of forming a government were shown by the impasse after the May elections and the necessity of a second round in June. After the elections, three pro-euro parties (New Democracy, the Panhellenic Socialist Movement (PASOK) and Democratic Left) formed a government, whose first promise to the electorate was the re-negotiation of the employment conditions of the bailout package. ${ }^{12}$

At this point, the Troika took a tough stance and required significant measures on the expenditure side in return for continuing financial assistance. Cuts in the government wage bill, pensions, and social benefits could not be avoided anymore and by November 2012, Greece actually performed better than the target (European Commission 2012c: 23). In return for compliance, the Troika extended the deadline of bringing down the deficit below $3 \%$ by two years, until 2016 . Furthermore, it also eased the terms of lending, amounting to a new $€ 40$ bn loan, al-

10 For the details of the program, see IMF (2012c: 45). A detailed, critical analysis of the restructuring is presented by Zettelmeyer et al. (2013), who notes the substantial costs the delay caused in the effectiveness of this measure.

11 The sheer volume of conditions is staggering - while the documentation of the first package was 90 pages (European Commission 2010), the second document was 185 pages long (European Commission 2012b). Some of the measures included a $22 \%$ cut in minimum wage, fully decentralised wage bargaining, and a 150,000 cut in public sector employment by 2015 .

12 See the report by the $B B C$, http://www.bbc.co.uk/news/world-europe-18564266. Accessed: July 27, 2013. 
though no one dared to call it a third bailout. ${ }^{13}$ As a condition for these relief measures, the medium-term fiscal plan of 2013-2014, which was signed in November 2012 , focuses mainly on the expenditure side - of the $€ 13.4$ bn adjustment, $€ 11.25$ bn is on the expenditure side (European Commission 2012c: 30).

When considering the subsequent rounds of Greek bailouts, the consequences of distrust become clear. Early on, Greece was blamed for its own troubles due to doctoring statistics as well as a long history of fiscal profligacy. Making it pay for its past sins was part of the bailout from the very beginning. The slippages in implementing the first package as well as trying to circumvent the conditions increased distrust towards the country and there was less empathy regarding the role of external factors in missing the targets. Increased distrust manifested itself in even tougher bailout conditions and even more detailed conditionality. As a result, Greece implemented the toughest adjustment package in the past decades without the benefit of improving its credibility.

\subsection{Ireland}

The Irish bailout negotiations provide a stark contrast to the Greek case. The country had a pre-crisis fiscal surplus and no history of doctoring statistics. Unlike in Greece, where even in the midst of the crisis populist promises and ridicule of austerity dominated the 2009 election campaign and increased taxation was seen as the cure for fiscal imbalances (Visvizi 2012: 21), Ireland took decisive steps from the very beginning to decisively address the crisis. In response to the banking crisis it immediately recapitalised failing institutions and created a bad bank (NAMA) to handle bad loans and increase confidence in the system. By January 2011 , it spent $€ 46.3$ billion or $29 \%$ of GDP on the bank bailout (European Commission 2011: 13). On the fiscal front the authorities focused on front-loaded adjustment and prioritised expenditure-based measures, including public sector wage cuts and reductions in entitlement benefits. As a result of these arrangements, when entering the loan program, there were no additional compliance burdens for the country and there were no measures that had not already been planned and in progress (Dellepiane - Hardiman 2012: 11). In other words, Ireland set its conditions for the bailout - an achievement later confirmed by IMF head Christine Lagarde (2013).

While there were speculations that Ireland would be forced to raise its low corporate tax rate, which was seen as critical for its ability to draw FDI and is resented

13 On the specific details of the package, see the Eurogroup statement on November 27, available at: http://www.consilium.europa.eu/uedocs/cms_Data/docs/pressdata/en/ecofin/133857.pdf

Acta Oeconomica 64 (2014) 
in some Continental European countries, ${ }^{14}$ the country could successfully withstand such pressures. It was also able to achieve a seemingly milder consolidation path than Greece and reach the 3\% deficit target only by 2015 (Table 1). While a possible reason is the higher level of initial deficit at 32\% of GDP in 2010, the high number is only technical, given the accounting for the bank consolidation. The underlying fiscal deficit was around 13\% that year (Dellepiane - Hardiman 2012: 13). In turn, the government committed itself to a front-loaded expenditure-based adjustment - between 2011 and 2014, a $€ 15$ bn fiscal program was proposed with $€ 10$ bn expenditure cuts and $€ 5$ bn revenue increase (European Commission 2011: 26-27).

From the beginning of the program Ireland received widespread accolades from Troika authorities and continued to outperform its carefully chosen targets (Table 1). This was the case even when targets were missed on paper. In 2011, the deficit reached $13.4 \%$ of the GDP instead of the targeted 10.6. However, bank capital injections were excluded from deficit calculations in the assessment, and thus a 9.9\% deficit was estimated (European Commission 2012a: 5). With Ireland's commitment to its program, risks were seen essentially in the external environment, which could hinder Ireland's export-based recovery strategy (European Commission 2013a: 37).

Overall, the Irish bailout negotiations had a very different dynamics than the Greek negotiations. Ireland had a strong pre-crisis record, and its policy-makers were more committed to neoliberal policies than most of their negotiating partners. Building on this reputation they were able to set their own conditions, which were comfortably met. This resulted in a situation when the $9.9 \%$ deficit in 2011 (13.4\% with bank support measures) was hailed as widely overperforming the target, while the $9.5 \%$ deficit in Greece during the same year was seen as a severe breach of conditionality. In 2012 - still with a deficit of $7.6 \%$ and a debt rate approaching $120 \%$ - the Irish Prime Minister, Enda Kenny was presented with a "European of the Year" award by German Magazine Publishers Association ${ }^{15}$ and was featured on the cover of Time magazine as producer of "The Celtic Comeback". The confidence in Ireland and not in Greece was strongly influenced by domestic political conditions to which I turn in the next section.

According to press sources, pressure to increase the corporate tax came from many corners, which include Germany, France, and the European Commission. See reports at http://www.spiegel.de/international/germany/merkel-s-dilemma-chancellor-faces-toughsell-on-irish-bailout-a-730578.html or http://www.bloomberg.com/news/2010-11-20/irishcorporate-tax-rate-increase-isn-t-a-condition-for-aid-sarkozy-says.html. Accessed: July 27, 2013.

15 See report at http://www.independent.ie/irish-news/germans-name-kenny-as-european-ofthe-year-28823213.html. Accessed: July 27, 2013. 


\section{PUBLIC ATTITUDES TOWARDS AUSTERITY}

By some standard measures, there seems to be no difference in public attitudes towards the crisis in the two countries. As it can be seen from Figure 2, there is little difference in how the Greek and the Irish public evaluates the national economic situation - steadily over $90 \%$ of the population believed even in 2013 that the economy is in a poor condition. These numbers certainly do not suggest Ireland as a success story.

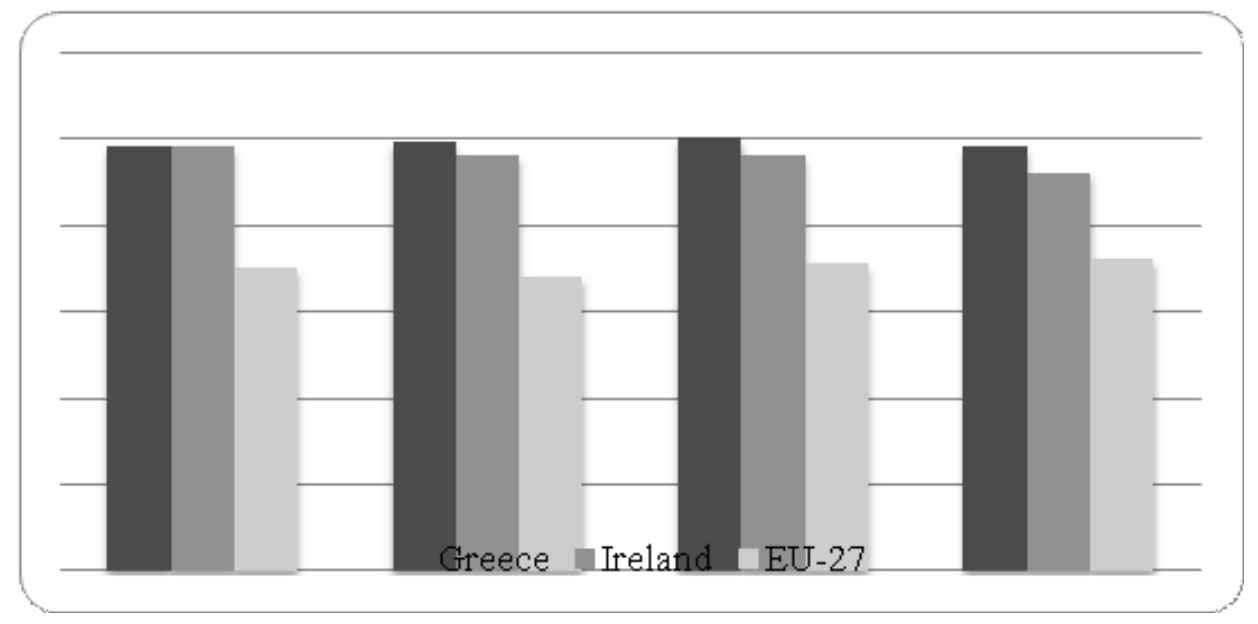

Figure 2. Assessment of national economic situation, 2010-2013 (\% total bad)

Source: Eurobarometer surveys (Nos. 74, 75, 77, 79) country factsheets.

Available: http://ec.europa.eu/public_opinion/archives/eb_arch_en.htm

There is also little difference in the electoral defeat of parties, which were held responsible for the crisis. The day of reckoning came earlier in Ireland, where the first post-crisis elections were held in February 2011. The ruling party, Fianna Fail suffered a historic defeat, receiving only $17.4 \%$ of votes, down from $41.6 \%$ in 2007, which meant that it lost 57 seats in Parliament out of $77 .{ }^{16}$ The elections were won by Fine Gael, which achieved its best result in history, winning 76 seats. A coalition government with the Labour Party was formed and headed by the already mentioned Enda Kenny.

Greece also registered historic changes in its traditional party system. While the elections of 2009, which were won by PASOK, did not yet reflect the crisis,

16 Election results are available at: http://www.electionresources.org/

Acta Oeconomica 64 (2014) 
the already mentioned elections in 2012 clearly did. However, unlike in Ireland, where the dominant party became discredited, in Greece basically all mainstream parties became discredited and new, extremist forces gained enormous influence. PASOK, which was held as most responsible for the crisis, got only $13 \%$ of the votes, down from $44 \%$ in 2009 . The elections were narrowly won by New Democracy by $19 \%$ of the votes, which was still considerably lower than its $33 \%$ performance in 2009. In contrast, The Coalition of the Radical Left (SYRIZIA) and the extreme right party, Golden Dawn, which both opposed the implementation of the bailout agreement, received $17 \%$ and $7 \%$, respectively. While the repeated elections in June could produce a narrow majority for the pro-bailout forces, the elections signalled the clear collapse of systemic support in Greece.

Figure 3 illustrates the difference with Ireland. While the assessment of the economic situation is about the same in the two countries, poor performance did not lead to the collapse of systemic support in Ireland. Although in the year prior to the crisis the two countries had about the same degree of satisfaction with democracy - a widespread indicator of systemic support - the experiences of the crisis led to the total collapse of trust only in Greece.

The maintenance of systemic trust in Ireland is strongly related to the belief in the necessity of austerity policies in the midst of crisis. In $2011,65 \%$ of respondents to the question of "How should we improve public finances" believed that

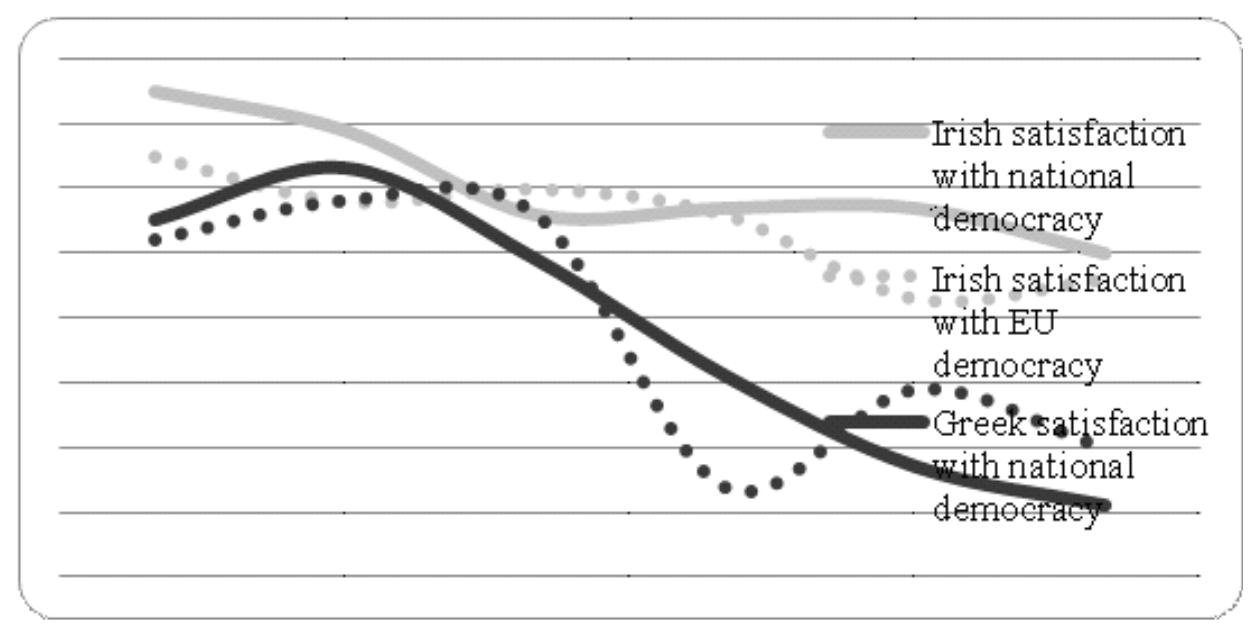

Figure 3. Systemic support in Greece and Ireland, 2006-2012

Source: Eurobarometer surveys (Nos. 65, 68, 72, 73, 76, 78).

Available: http://ec.europa.eu/public_opinion/archives/eb_arch_en.htm 
public expenditures should be cut, 18\% thought that both tax raises and spending cuts are necessary, while only $7 \%$ believed that the problem should be handled via tax raises (MillwardBrown 2011: 25). Even more striking is the lack of difference along party lines - over $60 \%$ of the respondents support expenditure cuts, while less than $10 \%$ believe tax raises to be the solution in every major party from left to right. This remarkable agreement on the course to be followed is probably the primary explanation of why, in stark contrast to Greece, there was almost no resistance to continued austerity. Left-leaning Irish analysts consider the collective memory of a successful period and of Ireland as an export-oriented economy as lying at the roots of these beliefs (Cosidine - Dukelow 2011; Fraser et al. 2013). The crisis was seen as the result of deviation from that path and thus it reinforced, rather than undermined belief in neoliberalism.

The Irish reaction was in a striking contrast with Greece, where protests were extremely widespread and strikes were supported by $74 \%$ of the population (Public Issue 2011). It is thus less than surprising that the government was highly reluctant in imposing expenditure-based measures and postponed them until they could no longer resist international pressure. However once such measures were implemented, a collapse of systemic legitimacy followed, as the government was no longer able to sustain the level of debt-financed consumption, which characterised the earlier decades. It is hard to escape the conclusion that lacking the memories of success in Ireland as an exporting base, Greeks are much less confident that the collapse of their old system will lead to a better system and there are deep divisions in society about the future.

\section{MARKET REACTIONS}

Relationship with the Troika as well as the public attitudes towards austerity is reflected in market reactions to the packages. Figure 4 shows monthly data for 10 -year government bonds. As we can see, until October 2009 there was basically no difference between the two countries. When Greece had to ask for a multilateral support program, rates started to rise. This rise was followed by Ireland a few months later, when the cost of bank guarantee became evident. The real divide, however, opened only in 2011 - while markets were clearly calmed by Irish measures, and by 2013 interest rates fell even below pre-crisis rates, Greece experienced enormous rates increases. Even though it eventually implemented the toughest fiscal adjustment program, ${ }^{17}$ it was unsuccessful in increasing market confidence.

17 According to the IMF (2012a: 8), Greece improved its structural balance by $17.5 \%$ between 2009 and 2013, which is by far the largest among advanced economies - with Iceland and Ireland coming second and third with a 5.6\% improvement, respectively.

Acta Oeconomica 64 (2014) 


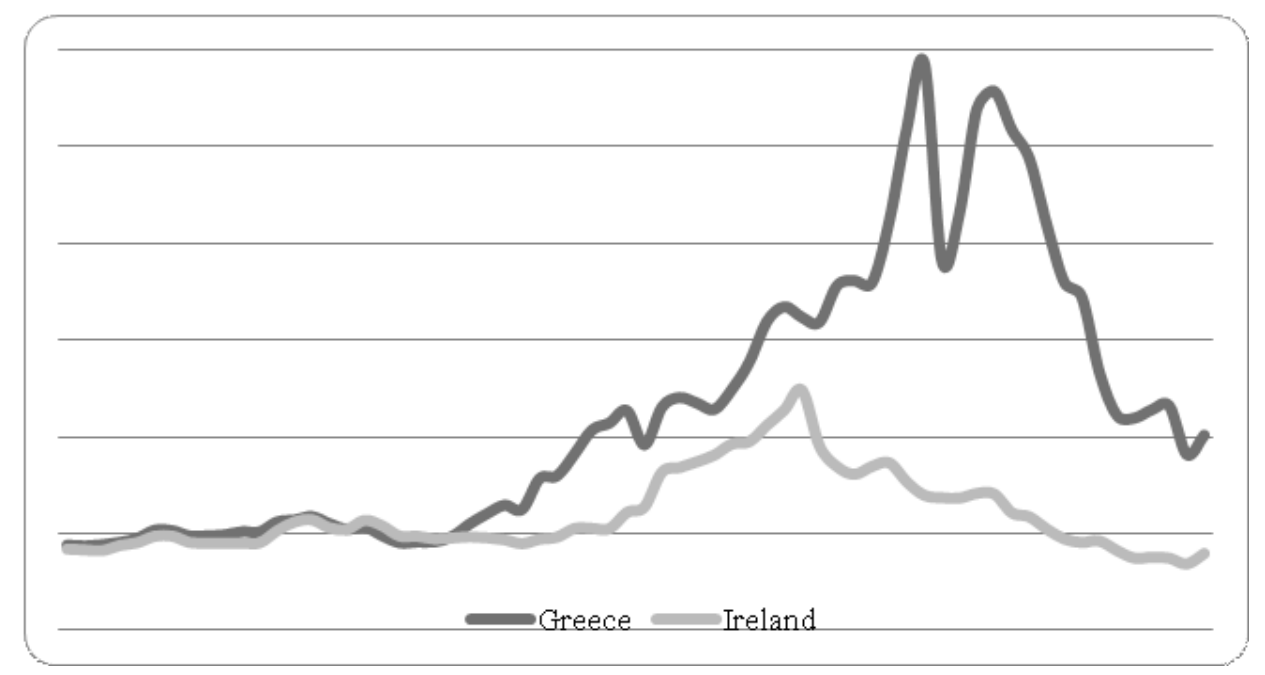

Figure 4. Interest rates on 10-year government bond (monthly data) 2008-2013

Source: ECB Statistical Data Warehouse.

Lack of market trust can also be seen in data on foreign direct investment. While Ireland continued to attract between US\$11-42 bn FDI throughout 2009-2013, Greece never achieved over 3 bn despite a large-scale privatisation program, which was announced in February 2011 (UNCTAD 2013: 213). An obvious reason for this outcome is that during the initial two years of adjustment, when tax-based measures dominated policy, the country was unable to implement structural reforms and improve its competitiveness. In the World Bank's Doing Business ranking the country continued to rank around 100th in 2011 and 2012. ${ }^{18}$

From the comparison of the two cases it appears that the decisive, expenditure-based Irish consolidation generated positive market expectations as claimed by theorists of expenditure-based consolidations. In contrast, it was not the size of austerity, which led to a loss of trust in the case of Greece, but rather the reluctance of governments to implement reforms, which would provide a lasting foundation for growth.

The different market reaction had an enormous weight on outcomes.

18 See the website of the report: http://www.doingbusiness.org 


\section{OUTCOMES OF CRISIS MANAGEMENT}

Based on the above two accounts, we can see the following chain of events. For different reasons, Greece and Ireland got into a serious financial crisis by 2010. Both implemented substantial adjustment with nominal unit labour costs falling to 88.9 in Ireland and 90.4 in Greece of their 2005 levels (European Commission 2013b: 98). Greece implemented fiscal measures around $€ 50$ bn between 2010-2012, with $€ 15$ bn further cuts foreseen to 2015. In 2010 GDP, the adjustment is close to 30\% of the GDP (Monastiriotis 2013: 5). Fiscal effort in Ireland was $€ 24$ bn between 2008 and 2012. For the period 2012-2015, a further 8.6 bn adjustment is planned, totalling around 20\% adjustment at 2010 GDP (Hardiman - Regan 2013: 10). The outcome of the effort of the two countries, however, differs sharply.

Figures 5-8 show the gap between expectations and reality in terms of growth and unemployment. The difference between the two countries is striking. Greek forecasts turned out to be extremely optimistic in hindsight, while a consistency between targets and outcomes could be observed in Ireland. Given that the two crises took place in parallel, international conditions cannot explain this divergence. Although it can be argued that the Irish economy is much more open than the Greek one and thus fiscal multipliers are likely to be lower, this fact was known beforehand, thus it does not explain the gap between outcomes and targets.

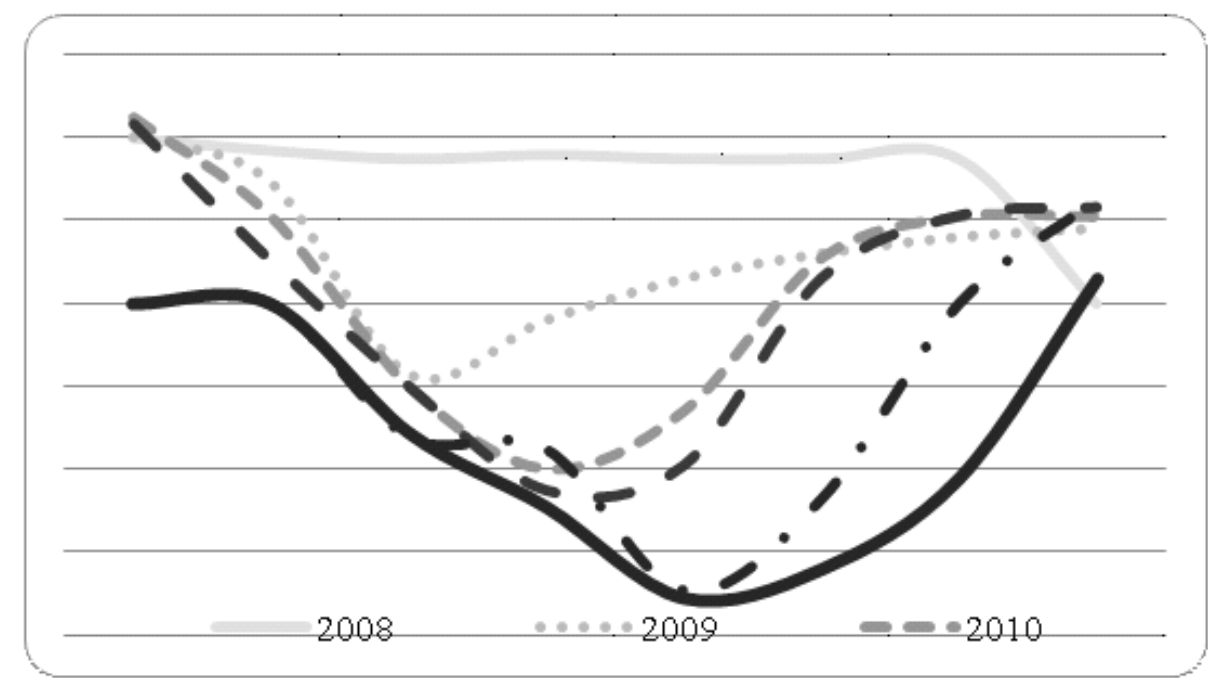

Figure 5. GDP forecasts and reality in Greece, 2007-2013

Sources: IMF (2008: 22, 2009a: 11, 2010a: 26, 2011a: 49, 55, 2013a: 36); European Commission (2012b: 16).

Acta Oeconomica 64 (2014) 


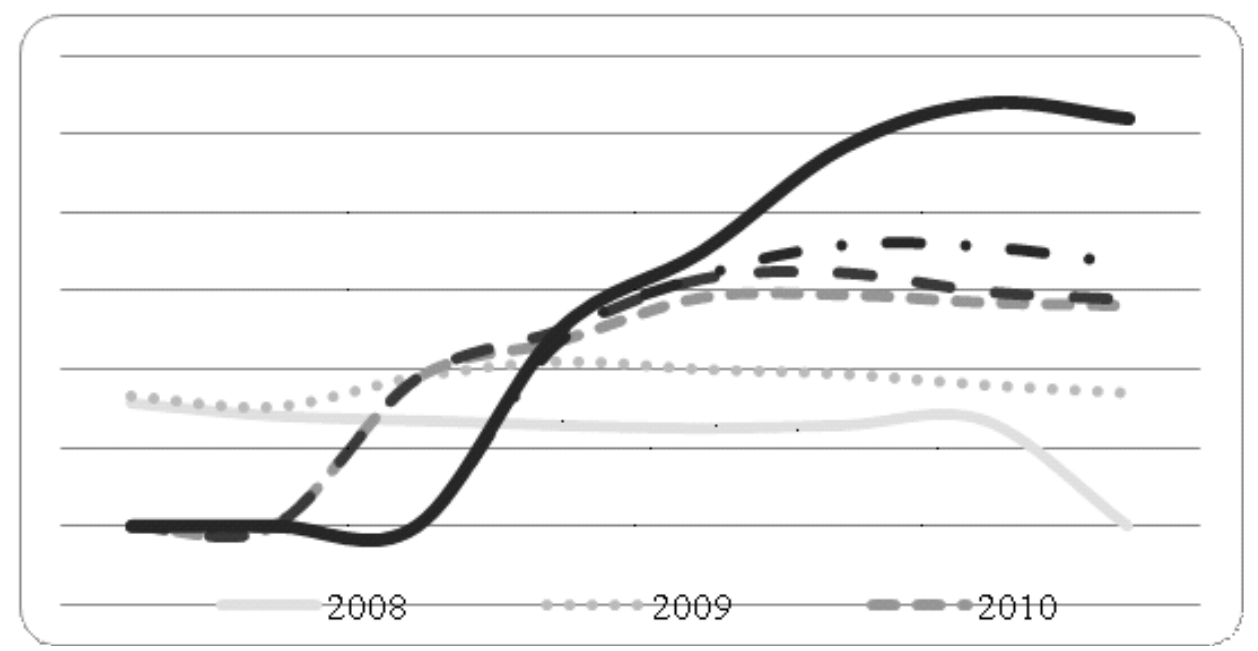

Figure 6. Unemployment forecasts and reality in Greece, 2007-2013

Source: See Figure 5.

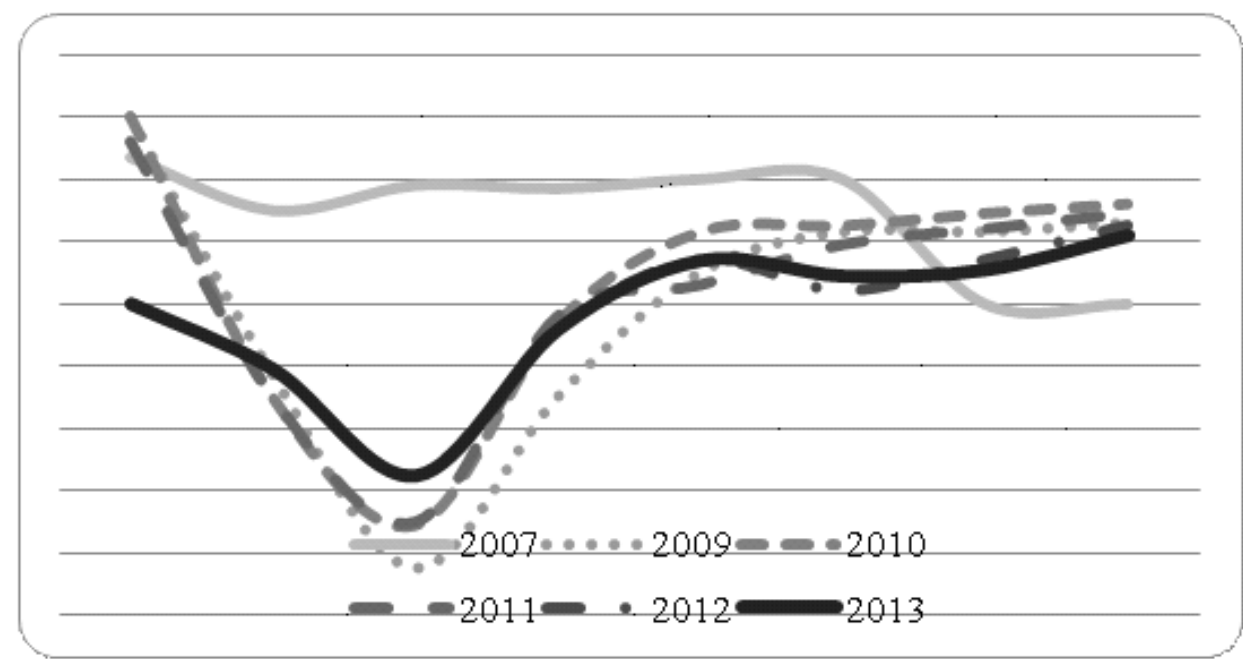

Figure 7. GDP forecasts and reality in Ireland, 2007-2013

Source: IMF (2007: 22, 2009b: 33, 2010b: 31, 2011b: 26, 2012a: 35, 2013c: 33). 


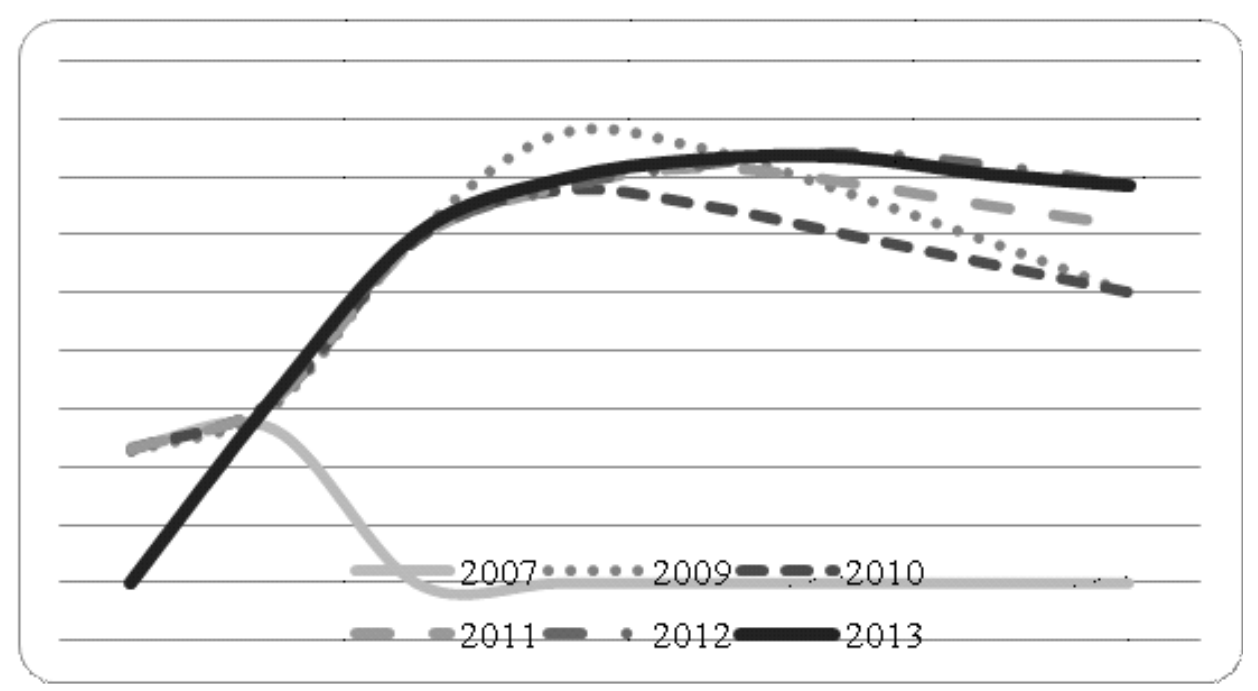

Figure 8. Unemployment forecasts and reality in Ireland, 2007-2013

Sources: IMF (2007: 24, 2009b: 33, 2010b: 31, 2011b: 26, 2012a: 35, 2013c: 33).

The excessive deviation from targets in the case of Greece raises critical questions regarding program design. In addressing this question, an IMF ex-post evaluation report emphasises the underestimation of fiscal multipliers and the "absence of a pick-up in private sector growth", which was expected as a result of structural reforms. The report refutes that there was a possibility for a more gradual consolidation path, arguing that the reason for this is that it would have required additional financing, which was politically not feasible (IMF 2013b: 20-22).

When we compare the Irish case with Greece, we can speculate about further reasons for the difference between the two countries. Ownership of the program and the presence and utilisation of local knowledge probably cannot be dismissed. Given the trust with international partners, Ireland was basically designing its own program and thus it could utilise local knowledge of its economy. In contrast, lack of trust towards Greece was partly driven by the history of doctoring statistics, which also implied that knowledge of the economy was much weaker, thus predictions were also more imprecise than in the case of Ireland. Such differences in initial conditions, in turn, started cycles, which magnified the difference while consistency between targets and outcomes ensured confidence for Ireland, regular missing of targets further undermined confidence towards Greece, regardless of its underlying efforts. During the prolonged negotiations over the bailout terms, the possibility of exit from the Euro zone was never off the table, which implied continued exclusion from markets and deposit flight from banks. 


\section{CONCLUSIONS}

The cases of Greece and Ireland provide an illustration about how past experience, trust, and expectations play a role in the emergence or absence of austerity traps. While in Ireland consistency between targets and outcomes limited the negative consequences of fiscal contraction, in Greece persistent lack of credibility undermined the gains in confidence expected from fiscal contraction. In these two countries neither the size nor the consequence of fiscal austerity was an independent variable. To a large degree, both depended on the presence or absence of trust in relation to the Troika, the public, and the markets. Lack of trust provides an explanation for the puzzle of Greek crisis management - in spite of the enormous consolidation efforts, there was no help from positive expectations, which would have helped mitigating the effects of austerity. In contrast, Ireland earned praise with a more moderate fiscal effort and successfully avoided a vicious cycle of austerity, which evolved in Greece following the collapse of trust after the failed first bailout package.

While conclusions from two cases have clear limitations regarding generalisability, there are two possible implications of this study. First, once we accept that fiscal stabilisation is not an independent variable, the debate on austerity and growth appears to be somewhat misplaced. Fiscal consolidation cannot be considered without government credibility - similarly to monetary policy, more credible actors can achieve better results at lower costs. Second, the two cases also show that expectations have a non-linear dynamic - while in times of global liquidity low government credibility does not necessarily have clear output costs, in hard times its effect is magnified. The main implication of this is that building quality institutions and basing legitimacy on good governance rather than populism appears an unavoidable task in preventing future crisis as well as austerity spirals.

\section{REFERENCES}

Alesina, A. - Perotti, R. (1995): Fiscal Expansions and Fiscal Adjustments in OECD Countries. NBER Working Paper, No. 5214.

Alesina, A. - Perotti, R. - Tavares, J. (1998): The Political Economy of Fiscal Adjustments. Brookings Papers on Economic Activity, 1: 197-266.

Ardagna, S. - Caselli, F. (2012): The Political Economy of the Greek Debt Crisis: A Tale of Two Bailouts. LSE Center for Economic Performance, Special Paper, No. 25. Available: http://personal.1se.ac.uk/casellif/papers/greece.pdf. Accessed: July 27, 2013.

Axelrod, R.M. (1984): The Evolution of Cooperation. New York: Basic Books.

Barry, F. (ed.) (1999): Understanding Ireland's Economic Growth. Houndmills - London: Palgrave Macmillan. 
Bechtel, M.M. - Hainmueller, J. - Margalit, Y. (2012): Sharing the Pain: Explaining Public Opinion towards International Financial Bailouts? MIT Political Science Department Research Paper, No. 2012-5. Available at SSRN: http://ssrn.com/abstract=2032147

Blanchard, O. - Leigh, D. (2013): Growth Forecast Errors and Fiscal Multipliers. IMF Working Paper, No. 13/1.

Boltho, A. (2000): What Matters for Economic Success? Greece and Ireland Compared. In: Bara, Z. - Csaba, L. (eds): Small Economies Adjustment to Global Tendencies. Budapest: Aula, pp. $150-169$.

Chrysoloras, N. (2013): Rebuilding Eurozone's Ground Zero: A Review of the Greek Economic Crisis. GreeSE Paper, No. 66. London: London School of Economics.

Considine, M. - Dukelow, F. (2011): Ireland and the Impact of Economic Crisis: Upholding the Dominant Policy Paradigm. In: Farnsworth, K. - Irving, Z. (eds): Social Policy in Challenging Times: Economic Crisis and Welfare Systems. Bristol: The Policy Press, pp. 181-198.

Cottarelli, C. - Giannini, C. (2006): Bedfellows, Hostages, or Perfect Strangers? Global Capital Markets and the Catalytic Effect of IMF Crisis Lending. In: Mody, A. - Rebucci, A. (eds): IMF-Supported Programs: Recent Staff Research. Washington, D.C.: International Monetary Fund, pp. 202-227.

Dellepiane, S. - Niamh, H. (2012): The Politics of Tough Budgets: The Eurozone Periphery 2008-2011. 19th International Conference of Europeanists organised by the Council for European Studies, Boston MA, 22-24 March, 2012. Available: http://hdl.handle.net/10197/4224. Accessed: July 27, 2013.

Drazen, A. (2002): Conditionality and Ownership in IMF Lending: A Political Economy Approach. IMF Staff Papers, Vol. 49. Special Issue, pp. 36-67.

Durlauf, S.N. (2001): Econometric Analysis and the Study of Economic Growth: A Skeptical Perspective. In: Backhouse, R. - Salanti, A. (eds): Macroeconomics and the Real World. Oxford: Oxford University Press, pp. 249-262.

Easton, D. (1965): A Systems Analysis of Political Life. New York: Wiley \& Son.

EC (2006): Measuring Administrative Costs and Reducing Administrative Burdens in the European Union. Working Document, No. 2006(691).

EC (2010): The Economic Adjustment Program for Greece. Occasional Papers, No. 61. Brussels: Directorate General for Economic and Financial Affairs.

EC (2011): The Economic Adjustment Program for Ireland. Occasional Papers, No. 76. Brussels: Directorate General for Economic and Financial Affairs.

EC (2012a): The Economic Adjustment Program for Ireland - Winter 2011 Review. Occasional Papers, No. 93. Brussels: Directorate General for Economic and Financial Affairs.

EC (2012b): The Second Economic Adjustment Programme for Greece. Occasional Papers, No. 94. Brussels: Commission of the European Communities Directorate General for Economic and Financial Affairs.

EC (2012c): The Second Economic Adjustment Programme for Greece First Review - December 2012. Occasional Papers, No. 123. Brussels: Directorate General for Economic and Financial Affairs.

EC (2013a): Economic Adjustment Programme for Ireland Spring 2013 Review. Occasional Papers, No. 123. Brussels: Directorate General for Economic and Financial Affairs.

EC (2013b): Statistical Annex of European Economy, Spring. Brussels: Commission of the European Communities Directorate General for Economic and Financial Affairs.

EC (2014): Statistical Annex of European Economy, Spring. Brussels: Commission of the European Communities Directorate General for Economic and Financial Affairs.

Fraser, A. - Enda, M. - Sinead, K. (2013): Deepening Neoliberalism via Austerity and 'Reform': The Case of Ireland. Human Geography, 6(2): 38-53. 
George, A.L. - Bennett, A. (2005): Case Studies and Theory Development in the Social Sciences. Cambridge, MA: MIT Press.

Giavazzi, F. - Pagano, M. (1990): Can Severe Fiscal Consolidations be Expansionary? Tales of Two Small European Countries. NBER Working Paper, No. 3372.

Gibson, H.D. - Hall, S.G. - Tavlas, G.S. (2011): The Greek Financial Crisis: Growing Imbalances and Sovereign Spreads. Working Paper, No. 124. Athens: Bank of Greece.

Grauwe, P. de - Ji, Y. (2013): Panic-Driven Austerity in the Eurozone and Its Implications. VoxEU, 21 February. Available: http://www.voxeu.org/article/panic-driven-austerity-eurozone-andits-implications. Accessed: July 27, 2013.

Guajardo, J. - Leigh, D. - Pescatori, A. (2011): Expansionary Austerity: New International Evidence. IMF Working Paper, No. 11/158.

Győrffy, D. (2009): Structural Change without Trust. Reform Cycles in Hungary and Slovakia. Acta Oeconomica, 59(2): 147-177.

Győrffy, D. (2013): Institutional Trust and Economic Policy: Lessons from the History of the EU. Budapest - New York: CEU Press.

Hardiman, N. - Regan, A. (2013): The Politics of Austerity in Ireland. Intereconomics, 48(1): 9-14.

Hardin, R. (2002): Trust and Trustworthiness. New York: Russel Sage Foundation.

Honohan, P. (2009): Resolving Ireland's Banking Crisis. The Economic and Social Review, 40(2): 207-231.

Honohan, P. (2010): The Irish Banking Crisis: Regulatory and Financial Stability Policy 2003-2008. A Report to the Minister for Finance from the Governor of the Central Bank. Dublin: Central Bank. Available: http://www.bankinginquiry.gov.ie/The\%20Irish\%20Banking\% 20Crisis\%20Regulatory\%20and\%20Financial\%20Stability\%20Policy\%202003-2008.pdf. Accessed: July 27, 2013.

IMF (2007): Ireland: 2007 Article IV Consultation. IMF Country Report, No. 07/325.

IMF (2008): Greece: 2007 Article IV Consultation. IMF Country Report, No. 08/148.

IMF (2009a): Greece: 2009 Article IV Consultation. IMF Country Report, No. 09/244.

IMF (2009b): Ireland: 2009 Article IV Consultation. IMF Country Report, No. 09/195.

IMF (2010a): Greece: Staff Report on Request for Stand-By Arrangement. IMF Country Report, No. $10 / 110$.

IMF (2010b): Ireland: 2010 Article IV Consultation. IMF Country Report, No. 10/209.

IMF (2010c): Will it Hurt? Macroeconomic Effects of Fiscal Consolidation. In: World Economic Outlook-October 2010. Washington, D.C. pp. 93-124.

IMF (2011a): Greece: Fourth Review under the Stand-By Arrangement. IMF Country Report, No. $11 / 175$.

IMF (2011b): Ireland: First and Second Reviews under the Extended Arrangement and Request for Reshaping of the Arrangement. IMF Country Report, No. 11/109.

IMF (2011c): Ireland: Third Review Under the Stand-By Arrangement. IMF Country Report, No. $11 / 276$.

IMF (2012a): Fiscal Monitor October 2012 - Taking Stock: A Progress Report on Fiscal Adjustment. Washington, D.C.

IMF (2012b): Ireland: 2012 Article IV Consultation. IMF Country Report, No. 12/264.

IMF (2012c): Greece: Request for Extended Arrangement under the Extended Fund Facility - Staff Report. IMF Country Report, No. 12/57.

IMF (2013a): Greece: 2013 Article IV Consultation. IMF Country Report, No. 13/154.

IMF (2013b): Greece: Ex Post Evaluation of Exceptional Access under the 2010 Stand-By Agreement. IMF Country Report, No. 13/156.

IMF (2013c): Ireland: Tenth Review under the Stand-By Arrangement. IMF Country Report, No. $13 / 163$. 
Ioakimidis, P.C. (2001): The Europeanization of Greece: An Overall Assessment. In: Featherstone, K. - Kazamias, G. (eds): Europeanization and the Southern Periphery. London: Frank Cass. pp. 73-94.

Jeanne, O. (1997): Are Currency Crises Self-Fulfilling? A Test. Journal of International Economics, 43(3-4): 263-286.

Kahn, M. - Sharma, S. (2005): IMF Conditionality and Country Ownership of Adjustment Programs. In: Mody, A. - Rebucci, A. (eds): IMF-Supported Programs: Recent Staff Research. Washington, D.C.: International Monetary Fund, pp. 119-130.

Keynes, J.M. (1936): The General Theory of Employment, Interest and Money. New York: Harcourt, Brace.

Kindleberger, C.P. (1989): Manias, Panics and Crashes. Second edition. Houndmills - London: Macmillan Press.

Krugman, P. (2013): How the Case for Austerity has Crumbled. The New York Review of Books, 60(10). Available: http://www.nybooks.com/articles/archives/2013/jun/06/how-case-austerity-has-crumbled/?pagination=false. Accessed: July 27, 2013.

Lagarde, C. (2013): Ireland and the European Union - Shared Determination, Shared Destiny. Speech in Dublin, 8 March. Available: http://www.imf.org/external/np/speeches/2013/ 030813.htm. Accessed: July 27, 2013.

Loizides, J. (2013): Are Greek Government Deficit and Debt Statistics Reliable? Journal of Economic and Social Measurement, 38(1): 79-95.

MillwardBrown Lansdowne (2011): National Opinion Poll 1st February, 2011. Available: http://www.millwardbrown.com/Libraries/Ireland Polls Downloads/Millward_Brown_Irish-Independent_Poll_January_2011.sflb.ashx. Accessed: July 27, 2013.

Monastiriotis, V. (2013): A Very Greek Crisis. Intereconomics, 48(1): 4-9.

Obstfeld, M. (1996): Models of Currency Crises with Self-Fulfilling Features. European Economic Review, 40: 1037-1047.

OECD (2010): Greece at a Glance: Policies for Sustainable Recovery. Paris.

Perotti, R. (2011): The Austerity Myth: Gain Without Pain? NBER Working Paper, No. 17571.

Public Issue (2011): Memorandum and Debt: One Year After. Available: http://www. publicissue.gr/en/1574/debt-afieroma/\#1. Accessed: July 27, 2013.

Regling, K. - Watson, M. (2010): A Preliminary Report on the Sources of Ireland's Banking Crisis. Dublin: Government Publications Office. Available: http://www.rte.ie./news/2010/0609/ reglingwatson.pdf. Accessed: July 27, 2013.

Reinhart, C.M. - Rogoff, K.S. (2009): This Time is Different: Eight Centuries of Financial Folly. Princeton: Princeton University Press.

Reinhart, C.M. - Rogoff, K.S. - Savastano, M.A. (2003): Debt Intolerance. Brookings Papers on Economic Activity, 34(1): 1-74.

Rosanvallon, P. (2008): Counter-Democracy: Politics in an Age of Distrust. Cambridge: Cambridge University Press.

Rothstein, B. (2000): Trust, Social Dilemmas and Collective Memories. Journal of Theoretical Politics, 12(4): 477-501.

Sabatier, P.A. - Jenkins-Smith, H. (1988): An Advocacy Coalition Model of Policy Change and the Role of Policy Orientated Learning Therein. Policy Sciences, 21: 129-168.

Shiller, R.J. (2000): Irrational Exuberance. New Jersey: Princeton University Press.

Soros, G. (1987): The Alchemy of Finance: Reading the Mind of the Market. New York: Simon \& Schuster.

Stix, H. (2013): Does the Broad Public Want to Consolidate Public Debt? The Role of Fairness and Policy Credibility. Kyklos, 66(1): 102-129.

Acta Oeconomica 64 (2014) 
UNCTAD (2013): World Investment Report 2013. New York - Geneva.

Visvizi, A. (2012): The Crisis in Greece and the EU-IMF Rescue Package: Determinants and Pitfalls. Acta Oeconomica, 62(1): 15-39.

Zettelmeyer, J. - Trebesch, C. - Gulati, M. (2013): The Greek Debt Restructuring: An Autopsy. Economic Policy, 28(3): 513-563. 